\title{
GDNF Gene
}

National Cancer Institute

\section{Source}

National Cancer Institute. GDNF Gene. NCI Thesaurus. Code C28465.

This gene is involved in neurogenesis. It plays a role in promoting the differential and survival of neurons. 